Сибирские исторические исследования. 2018. № 2

UDC $27-565$

DOI: $10.17223 / 2312461 \mathrm{X} / 20 / 12$

\title{
A RITUAL OF DEATH OR LIFE? THE CASE OF RADONITSA IN THE SMOLENSK REGION, RUSSIA
}

Irena Mostowicz

\begin{abstract}
The author describes the ritual of radonitsa in the Smolensk region of Russia. The ritual is a remembrance holiday taking place usually on the first Tuesday after Russian Orthodox Easter. People meet at the cemetery and act out a particular ritual with offerings including food and alcohol at the graves of their deceased family members. The goal of the article is to find out the origins of the ritual and explore its continuity, meaning and framing at present. This article uses historical and anthropological perspectives which, in comparison to other scientific publications on this rite, focus on analysis of contemporary ritual performance in a particular place. It also presents a historical transformation of the rite from pre-Christian times to the $21^{\text {st }}$ century. The analysis of the ritual also features a cross cultural approach: the influence of radonitsa can be observed among other religious and ethnic minorities living in the Smolensk region today. The ethnographic data was gained through participant observation and interviews in the Smolensk region in 2016.
\end{abstract}

Keywords: radonitsa, ritual, Orthodox Church, Smolensk

\section{Introduction}

Death as part of human life has always been an important element of culture. It is also one of the most important philosophical phenomena which helps people to understand the reality of life as something meaningful. Even if death is related to a feeling of sadness, due to the loss of a close person, it still brings some positive moments with it. This kind of moment is a remembrance which might be considered as the passage from the world of death into the world of life (van Gennep 1960: 164). The remembrance of ancestors gives a feeling of connection to generations and enables them to bond with the past. For centuries death was connected to particular rituals. In many cultures death rituals stand at the centre of social life and are often characterized by a festive celebration (Huntingdon, Metcalf 1991: 10). Celebrations begin with the preparations for a funeral and continue afterwards with activities like a wake and remembrance ceremonies. All such activities are aimed at remembering the departed and bringing people together through mourning.

In 2016, I did my fieldwork in the Smolensk region of Russia. My research was related to everyday life. My interlocutors once mentioned that 
during the Easter season they needed to prepare for radonitsa. Since I had never heard about anything like that before, I asked them to let me participate in preparations. People, with whom I cooperated, were surprised at my lack of knowledge: "You mean you never heard about radonitsa?" In this way I discovered a very peculiar element of my small research group's daily life: a remembrance ritual which has been celebrated by their families for generations. Very soon I discovered that this ritual is an absolutely typical element of Easter celebrations in this particular region. Moreover, the literature research I did showed that the borderland region, where Smolensk is located, has kept a characteristic commemoration rite, which is systematically spread to other Russian regions, being perceived as an Orthodox tradition. Meanwhile, I was interested in the origins of the rite. I wanted to find out how the ritual evolved, why people perform it today and what meaning the ritual as such bears ${ }^{1}$.

Thus, the Smolensk region can be seen as a place, where some specific forms of commemoration rituals, which are different than in other places, i.e., Western Europe, have survived and radonitsa is an example of this.

Furthermore, in Smolensk I observed minority groups, which adapted to the ritual of radonitsa. The region is inhabited by two significant minorities, Roma and Jews, who are visible in the public space and who make radonitsa a part of their everyday life. The religious majority of the region consists of Orthodox Christians. This article presents a comprehensive picture by showing how all the three groups interact, while being very different from each other. They share one ritual, in one place at the same time, but in different ways. History also plays an important background role for the analysis of the ritual adaptation by the three groups. The historical analysis of radonitsa, as well as of Russian history, serves to give a detailed picture of this phenomenon.

As mentioned above, the rite attracted my attention as something unusual personally to me. Also, as it will be presented radonitsa is performed nowadays in other Russian regions as well, but according to historical literature, its core in Russia seems to have stayed in the Smolensk region. The ritual is closely associated with Orthodox Easter. This is the reason why it is perceived as a part of the Russian Orthodox tradition.

On the first Tuesday after Easter people go to cemeteries to visit graves of their family. A central element of the celebration is feasting at the graves: people gather around a grave which plays the role of a table covered with a tablecloth. They consume food and alcohol believing that their ancestors join them to celebrate together. The festival has a very joyful character. It takes place in spring when nature rejuvenates after the cold Russian winter. The festival is not only for the closest family members; it is characterized by hospitality and warmth because family members invite their acquaintances to join them.

The historical background of radonitsa displays a very long continuity of the same style of commemoration rituals and dates back to ancient times. 
This historical element is missing from a great variety of scientific materials from mostly ethnographic and folklore studies (e.g. Sokolova 1979; Kazakova 1995; Agapkina 2002; Pankeev 2008; Listova 2015). This article aims to fill this gap. Authors do not address the history in their analysis of radonitsa. They for the most part describe the ritual in a general way, presenting similarities or differences between the regions where the same or similar celebrations occur. Meanwhile, some historical anthropological research shows that radonitsa has a rich and ancient heritage (e.g. Fisher 1921, 1923; Lewicki 1955). The tradition of feasting at graves to commemorate one's ancestors can be observed in remote geographical places and ethnic groups. As a historical analysis will later show, radonitsa in the Smolensk region portrays a continuity of these ancient traditions. The belief that a soul has the same needs after death as a living person comes from ancient Egypt, Greece and Rome.

Generally, rituals play an important role in culture. They construct particular stages of life and build a certain life order. The theoretical framework applied shows how the ritual of radonitsa can be analyzed through its particular elements.

The research results are based on participant observation and interviews with interlocutors who agreed to include me in their private circle. The protagonists of this article show how they tried to cope with the mystery of death.

The structure of the article is as follows: first, I discuss the theoretical approach used; next I describe the history of radonitsa; and finally, I present the ethnographic results of my research: how the ritual is celebrated by the Orthodox population and by the Roma and Jewish minorities.

\section{The Meaning of Rituals}

Rituals are specific forms of performative and symbolic actions that are associated with many areas of life. Max Gluckman claims that rituals are functional since they transform conflicts and channel them in a harmless direction. Participants are necessary: they show interaction between individual motivations and societal functions (1954: 34).

For Arnold van Gennep rites are based on a belief that natural or acquired characteristics are material and transmissible (1960: 7).

Rites are procedural, transformative and dynamic, but they are also characterized by a constant repetition of action sequences (Michaels 2003: 4). Rituals influence people and are actively shaped by them. Moreover, rituals represent and reinforce social, cultural or political orders. The concept of a complex ritual executed by certain social roles that are supported by a group can be singled out, too. These officially accepted forms of action aim to create a kind of logic to reduce the uncertainty of human action. This action is constantly updated and adapted (Michaels, 2003: 5-6). 
The different stages of a ritual can be distinguished in the form of the general standard specification levels in a general concept of framing. Framing means the social organizing principles of perception of the events. Included in the concept of framings are procedural aspects such as speech acts (Who says what?; Where is the beginning and end of a ritual?), metacommunicative framing channels (e.g., facial expressions, gestures), space (Where does the ritual take place?), material culture (e.g., decor, costumes, symbolic objects) and actions (such as dancing, etc.) (Ambos, Weinhold 2013: 4-7).

The significance of the ritual background depends not only on a mythological belief or ideological assumptions but also on the context. The historical and socio-cultural environment together can play a part which is as important as the ideological aspect. Rituals can be analyzed in the form of tools for the design of social realities. Rituals are shaped by their social context because they are a central element of cultural practices generally as they are crucial in shaping and changing the cultural configurations (Kapferer 2008: 507).

All these theoretical elements can be easily recognized in the ritual of $\mathrm{ra}$ donitsa.

\section{The Origins of Radonitsa}

The cult of ancestors is an important element in many religions and cultures. The analysis of ancient rituals shows that the rite of radonitsa has a very long tradition; offering food and organizing celebrations in honour of the departed were practiced for centuries by many groups in different regions. Bringing food to a grave was a very characteristic custom in many pre-Christian societies in Europe (Fischer 1921: 351).

The Torah, or Old Testament, describes how the Israelites sacrificed harvest and animals to their God. In ancient Egypt, in India, as well as in Persia, food offerings to spirits and organizing feasts as a part of commemoration were a common practice. Very often such ceremonies were organized during the spring as in the case of radonitsa. In ancient Greece, special rituals at the graves were performed while people were feasting and drinking after a funeral. Moreover, the custom of celebrating a dead person's birthday was also popular then. On this day the person's relatives brought pots with food, usually broad bean, fish, fruits, as well as drinks, i.e., honey and milk to the grave (Fisher 1923: 6). This tradition was later adopted in the Roman Empire.

In medieval times, the Christian Church wanted to destroy all pagan traditions but this took ages to do. Archaeologists and historians have proven that pagan rituals in the former Roman territory endured into the Middle Ages. Libations at cemeteries were still popular in Italy in the $9^{\text {th }}$ century (Fischer 1923: 9). In Romania people used to bring bread and wine to the graveyards of the dead until the $20^{\text {th }}$ century. In France, Germany and among the Southern 
Slavs the Roman tradition of sprinkling a grave with alcohol was documented as a tradition existent in the first centuries of the Christian era.

Later the fight against paganism intensified, especially in the newly Christianized regions like Poland or Lithuania. In 1428, the Synod of Riga forbade bringing food and drinks to churches and cemeteries. In the $15^{\text {th }}$ century, benches would be put next to graves so that the people could spend some time with the departed ${ }^{2}$ (Fischer 1923: 17-18). Bishops were worried about the fact that in the early $20^{\text {th }}$ century Polish province peasants still offered food to priests in churches during the All Souls Day. The custom of bringing food to the church rather than to the graveyard reflects the persistence of the old pagan traditions among the people. People often celebrated remembrance days at home by organizing feasts. Later food leftovers were offered to a priest and not to the dead. Such a long presence of pagan traditions in Catholic countries is explained by a slow but systematic and progressive propagation and establishment of the Catholic order, which expanded from the centre to the periphery.

Although Eastern European inhabitants considered themselves to be Christian, they still practiced some pre-Christian rituals, sometimes even without knowing their origins. As the analysis of radonitsa will show, these rituals still take place. Nevertheless, feasting and libations so characteristic of ancient Greece remained popular mostly among the Eastern Slavs.

Feasting rituals, like radonitsa, are considered to have come through Bulgaria to Eastern Europe with Byzantium (Fischer 1923: 13). In the $19^{\text {th }}$ century, people believed that only the Byzantine influence, not the Western Catholic tradition, had an effect on the Orthodox tradition (Janion 2006: 76). The word $r a-$ donitsa is believed to have its origins in the ancient Roman ritual "dies rosarum" or "rosalia" which has a very similar framing (Fischer 1923: 43). Furthermore, some scientists emphasize the prefix- rad - which in Slavic languages indicates joy since the ritual always had a positive character (Gołąbek 1926: 41).

Many Arab travellers and merchants observed and described rituals similar to radonitsa in the regions of contemporary Serbia, Bulgaria, the Czech Republic, Poland and Ukraine. Descriptions can be found in the texts from the $9^{\text {th }}$ to $10^{\text {th }}$ centuries (Fischer 1923: 19). Feasts during burial ceremonies were organized in accordance with a general belief that a dead person has the same need for food and fun as during his / her lifetime. The conception suggested that there is life after death and that this life has the same elements of everydayness as the one preceding death (Kupisiński 2006). Moreover, Arabs observed remembrance ceremonies during the anniversary of someone's death. In Russia and in the Balkans there were libations made on such days: alcohol was brought in the pitcher and consumed; after that, people returned to their homes (Lewicki 1955: 129-130).

In comparison to the Catholic Church, the Orthodox Church accepted some pre-Christian customs due to its softer policies. Years of inquisition, 
violence against pagan traditions and strict dogmatism helped the Catholic Church to educate people in a new way. The Orthodox Church adopted Byzantine customs and never created an institution which would fight against all undesirable elements. Even though paganism was considered anti-Christian, many pre-Christian customs were able to survive in an unchanged form. $R a$ donitsa is a great example of such a custom in the Eastern Church whose Orthodoxy did not reject those rights as they did not contradict the Gospels. This process is framed as the churching of a folk culture (Rachinsky, Fyodorov 2016: 6).

Another explanation for radonitsa's current presence lies in the issue of the United Church. Its formation was a result of political processes in Poland in the $16^{\text {th }}$ century when the Smolensk region belonged to Poland. It was created to unify the Orthodox order with the Pope as its head and its presence is typical for the today's border region (Belarus, Ukraine and Russia). Since the United Church did not interfere with the old pagan commemoration rituals, these were able to survive. In the late $18^{\text {th }}$ century, this area was annexed by Russia and the United Church lost its position to the Orthodox Church. The Orthodox Church tried to transform some United Church rituals and reestablished them in the same form but in a different period of time. Radonitsa is an example of this kind of ritual which was initially practiced in autumn (as an equivalent of the rite dziady celebrated in Belarus) (Janion 2006: 75). The traces of the United Church may also be found in the Smolensk region nowadays. For instance, in Lubavich village one church survived World War II relatively unscathed but despite the fact that it remains closed and inactive today, still it reminds us of the united community which existed here before the war.

The fact that modern culture has been less influential in Russia is believed to be another reason for the preservation of some pagan rituals. The early modern period and scientific progress destroyed the last remnants of paganism in Western Europe (Fischer 1921: 39).

Finally, using the term pagan is not quite adequate in the case of radonitsa celebrations. Informants who took part in this research consider themselves to be Orthodox only. No one of them has ever thought about the origins of this rite. Moreover, they treat it as a natural element of their daily life.

\section{Radonitsa in the Smolensk Region}

For an outsider who has never had contact with this kind of ritual before, radonitsa is an extraordinary event, intriguing and fascinating at the same time, since food and alcohol consumption at the cemetery is not always a popular commemoration activity in other regions today.

Radonitsa is a rite which emphasizes family and social connections. It is a social-religious holiday which is a significant event for a community. 
The main goal of the ritual is maintaining social bonds within the community both in a village where the people have known each other well for generations and in a town where celebrations are participated in by family and relatives.

Inhabitants of the Smolensk region find radonitsa a very natural element of their everyday life and do not even think about its meaning or history. This practice is also noted by other researchers (Listova 2015: 62). The absence of self-reflection means that people are accustomed to the rite. Among the people, with whom I had contact, the overwhelming majority celebrate radonitsa because this ritual was also performed by their parents and grandparents, thus displaying a generational connection. Usually, the whole family goes to the cemetery with parents taking their children and sometimes some other relatives along. Asked about conveying knowledge of the rite to children, a man in his forties told me:

If children ask why we celebrate it, I can explain that it is a custom, but basically everything is clear: everyone does it. We all know how to do it.

Those words suggest a general belief about the order existing from time immemorial, which is well known to everyone and is followed by everyone, even children who through observation and participation obtain necessary knowledge and practice will successfully perform the same rite in the future.

This conviction is interesting, since it goes somewhere far from the general explanation of radonitsa, which mixes the Slavic tradition with the Orthodox one: Eastern Slavs used to have the custom of symbolic feeding of their ancestors. It consisted in either leaving food in front of the house or calling the spirits to come and join the living members of the family. It was believed that the souls of ancestors would come to the Earth before Easter and join their families (Agapkina 2002: 45). An evident pagan ritual - food offering - was adapted to a new religion - the Orthodox one - thus the holiday of Easter became a time frame for a commemoration rite.

Easter which takes place in spring is a symbolic holiday. The resurrection of Jesus Christ can be compared with spring as a season of nature's revival. In this respect, a belief in the return of ancestors to the Earth makes a lot of sense. They cross the passage from the world of death to that of life. By returning to the last place they were in in life, that is, a cemetery, they join their families and spend time celebrating together in the framework of Orthodox Christianity.

According to official sociological statistics, around $75 \%$ of the Russian society today considers itself to be Orthodox ${ }^{3}$. A significant social revival of religiousness can be clearly observed nowadays, especially after the long period of atheism. Participation in religious events, considered to be obligatory until 1917, was difficult in Soviet times (Sokolova, Yudkina 2015: 6). The communist regime abolished the Orthodox Church's control over the 
main fields of human everyday life, i.e., over weddings, births and deaths. Although town halls took over the role of the church, some people remained religious as in the case of my informants from the Smolensk region. Radonitsa can be perceived as this kind of religious example being celebrated by many people during Soviet times. The ritual was usually associated with the Orthodox tradition. One of the interviewees, an old woman aged 67, told me:

Sure, we celebrated radonitsa. Of course, during Soviet times it was not desirable to show it. It was forbidden. On the other hand, everyone knew about it and no one said anything. There were no security checks in the cemetery, so everybody could easily go there. Also, the main cathedral was open all the time. It was never closed. People attended Easter and Christmas services [...] Nowadays, radonitsa is a day free of work but in the past it was not like that. We went to the cemeteries after the end of the working day.

Hundreds of people did it everywhere.

This quote shows two interesting aspects. First of all, the informant emphasizes the lack of state intervention into the performance of the ritual, mentioning the period of the 1970 s to the 1980 s, a time which was politically more liberal than the Stalin era. Later, during the Brezhnev era the state made it possible for the people to have more privacy than there had been under Stalin. The freedom of observing remembrance customs can be considered as one of the elements of private life. Living in a collective was the main principle of social life in the USSR. The Bolsheviks implemented this concept, for example, through mass demonstrations and social organizations which organized human life from early childhood. All those elements suggest being a part of a larger group. Socialism built an impressive public sphere with the people engaged in social life. In comparison to that, a cemetery and remembrance of a family member were seen to be part of the private sphere and here the authorities showed some respect towards the intimate nature of the activity. The woman emphasizes that people had the possibility to celebrate the ritual and its enactment was not hindered, even though it was officially forbidden. Unofficial celebrations of religious festivals in public, with a cemetery being a public space of a kind, depict an interesting image of the late period of socialism. The possibility of this religious enactment runs counter to the general belief in the repressive and dogmatic character of the Soviet system.

Furthermore, the speaker believes that radonitsa is celebrated in all the other regions as well. On the one hand, this statement might be perceived through the previously mentioned belief, with the rite being a part of the local life forever. On the other hand, the adoption of the ritual by the Orthodox Church made the rite popular in other regions of Russia, and nowadays it is believed to be a Russian commemoration tradition (Listova 2015: 56). Thus radonitsa can now be observed in places far away from the Russian- 
Belarussian-Ukranian borderland, i.e., among the Komi-Permyaki group in the Perm region (Chugaeva 2010: 200) or in some parts of Siberia where the rite was transmitted by the migrants from Belarus (Dayneko 2016: 68). Nevertheless, many of my informants from different age groups outside the Smolensk region had no knowledge of the ritual. This means that through the Orthodox Church a spread of the ritual may slowly proceed and be adapted by others in the future.

Since radonitsa is seen as a religious commemoration ritual, it contains some elements also present in the Easter celebrations: bringing coloured eggs and saying a Paschal greeting "Khristos Voskrese" meaning "the Lord has risen" (Agapkina 2002: 280; Listova 2015: 63). The egg is an important symbol of Easter and is considered to symbolise new life in the Christian tradition (Kopalinski 1997: 214). Tatyana Agapkina in her research on Slavic folklore traditions claims that bringing eggs to a grave is meant to inform one's ancestors that Easter has arrived and it is time to come and join the family (2002: 281). This setup symbol can be interpreted as a first sign of radonitsa being the ritual of life. Moreover, it is strongly connected to the origins of the rite, particularly to the topic of food and its sacrificing. It shows a transformation of the ritual from ancient times to the present.

The general festive and positive atmosphere during the rite is another sign of radonitsa being the ritual of life. The element of joy is included already in the rite's name - rad - which is the root of radost', that is, joy. During the commemoration people are not as sad as during a funeral or a wake. Both ceremonies are a time of departure when a dead soul is heading to the world of death. During radonitsa all family members become connected, and so it is a cheerful moment of connection in the world of the living. Jesus, rising from the dead, makes Easter a holiday of joy, with life achieving victory over death. Thus the radonitsa celebration is positive character. In the past, it was very often linked to some particular games like egg rolling on a grave, telling jokes and even dancing. In this way people wanted to emphasize the power of life (Sokolova 1978: 113-122). The positive nature of radonitsa was often mentioned by my informants. One of them, a man aged 43, told me:

Radonitsa is a very special moment for each family. I remember this festival from my early childhood as a very magical moment. After the Easter night service my mom woke me up and during the preparations before going to the cemetery, she drew a coloured egg around my face. It was the most beautiful and intimate moment between us. She did it to bless me and ensure me good luck and good fortune. Radonitsa was always celebrated together with the other family members, neighbours and friends. We visited other graves, drank and ate with the families of people we knew. It is a holiday which brings people together. $<\ldots>$ Zdmitrovka is of a completely different nature. We celebrate it in November. It is also a remembrance day but it is more private because we only visit the 
graves of our parents and grandparents and we do not make any other visits.

For this man the ritual of radonitsa has even some magical element to it. He associates it with his mother and the special moments they shared on this day. The issue of memory is relevant here as it is clear that the knowledge about the celebration was transferred to the man by his family. For him the positive memories also present a special role of social life which the rite is associated with. The mystery of death is not frightening or sad for anyone. People spend the day together in a group, either in a small family circle or in a larger group of relatives and acquaintances. During this day people are united by the memory of the departed. The meta-communicative activity of remembering the people they knew brings them together and through that they feel to be part of a larger community. Being a member of a group evokes a good feeling because it forms an identity based on shared memory. The common practices like drinking and eating together are a binding element, the culmination of the ritual. Whereas radonitsa is characterized by its social character, zdmitrovka is largely private, with only relatives and no friends taking part.

Furthermore, my informant mentions a more intimate aspect performed in the private sphere between him and his mother: moving a coloured Easter egg around his face. A coloured egg is an element of Easter. Eggs are boiled in water containing onions so that they later could obtain a characteristic red colour. This personal rite can be perceived as a preparation ritual for radonitsa.

Cleaning the grave before radonitsa is a very important element of preparation as well. The family members need to visit the cemetery a few days before to clean the grave from grass and leaves and put flowers (usually artificial ones) on it, and, if necessary, to restore the grave, i.e., by painting the fence around it. This process can be compared to the preparation for hosting a guest at home in terms of cleaning and creating a welcoming atmosphere. The same happens here: since a soul should come back to the world of life, this visit should be properly prepared.

The next step is food preparation. Women making pancakes for radonitsa were documented already in the $19^{\text {th }}$ century in the Smolensk region (Agapkina 2002: 271). Flat cakes are still the main ritual meal prepared. One man in his forties told me about how this food is made in his family:

When it comes to food, pancakes are required. We make them with the stuffing like caviar and salted fish. Usually we also bring some sausages, bread, fruits and vegetables. We drink only vodka. We do not say anything special. When we start, we just drink three glasses to my parents and have a snack. We pour a bit of vodka on the grave and put a piece of bread or sandwich on it as well.

Here we can see not only the elements of feasting but a scenario of the rite. This man considered radonitsa as something incredibly normal. A tech- 
nical description of the actions displays the feeling of a routine procedure. His words reveal a very symbolic picture: a son organizes a feast for his parents; even without any words he invites the souls of his ancestors to join him. To do so, he pours alcohol on the grave and leaves a piece of food on it as well.

Words are an important part of radonitsa, according to some authors describing the ritual (Kazakova 1995; Agapkina 2002; Listova 2015). In the case of my informant, words were never mentioned as something sufficient. The expression "everyone celebrates it in their own way" was said very often. The man in the above quote said "We do not say anything special". My observation showed that the people performing the rite in the presence of the closest family members were mostly focused on consumption. The scenario was a bit different when other people joined in the ritual as the hosts displayed greater hospitality to their guests.

Even if the goal of the rite is to preserve the memory of someone's ancestors, acquaintances and strangers are welcome. I experienced that hospitality once when I was invited by a family, having been noticed with their neighbours at the cemetery. When the family came to the cemetery carrying food for radonitsa, they noticed their neighbours who took me along so that I could observe how they cleaned the grave before radonitsa. These neighbours immediately invited us to join in and celebrate the holiday with them. Thus, the family fulfilled the rite of incorporation which reunites all the surviving members of a community and a deceased person in order to restore the chain broken by death (van Gennep 1960: 164). By virtue of their hospitality they not only incorporated me into their community but they also incorporated their ancestry into the world of life.

Alcohol consumption came first. First, a few drops of vodka were sprinkled around the gravestone; then we sat around the grave and laid a tablecloth on it. A tablecloth is important for the rite since it turns a grave into a festive table for the living and the dead alike (Listova 2015: 72). People usually use a special tablecloth, the one used only for radonitsa. It must be of a particular size and look festive enough.

It is important to mention that benches (and sometimes even tables on which visitors can put food) are placed around the graves. If there is no special table, offerings are left on the tablecloth on the grave. In the case of the ritual in which I took part on that day, we sat on two benches opposite each other, on either side of the grave.

A shot of vodka or cognac is served by the closest relative of the departed (child, widow / widower or parent) to the other visitors. In this case it was a widow who came with her children to commemorate her husband. As the drinking continued, people recalled good stories about the deceased. The feeling of loss was strongly present but there was an intense sense of unity among the visitors as well. Later we ate food which included pancakes, 
cucumbers, apples and some candies. We also continued drinking while commemorating the deceased. This part of the ritual is closely associated with reflection: people vividly recall things relating to the deceased person that had happened in the past and analyze their own behaviour. This is equally a moment of reflection about the present and the future. They ask themselves in a kind of inner dialogue: "How can we live without you now and how will things be later?" This reflection can be perceived as a kind of bonding with the deceased by treating him or her as a real participant of the feast. After the meal people left some food and alcohol on the grave. The alcohol usually evaporates from a glass in a few days and the food is eaten by animals.

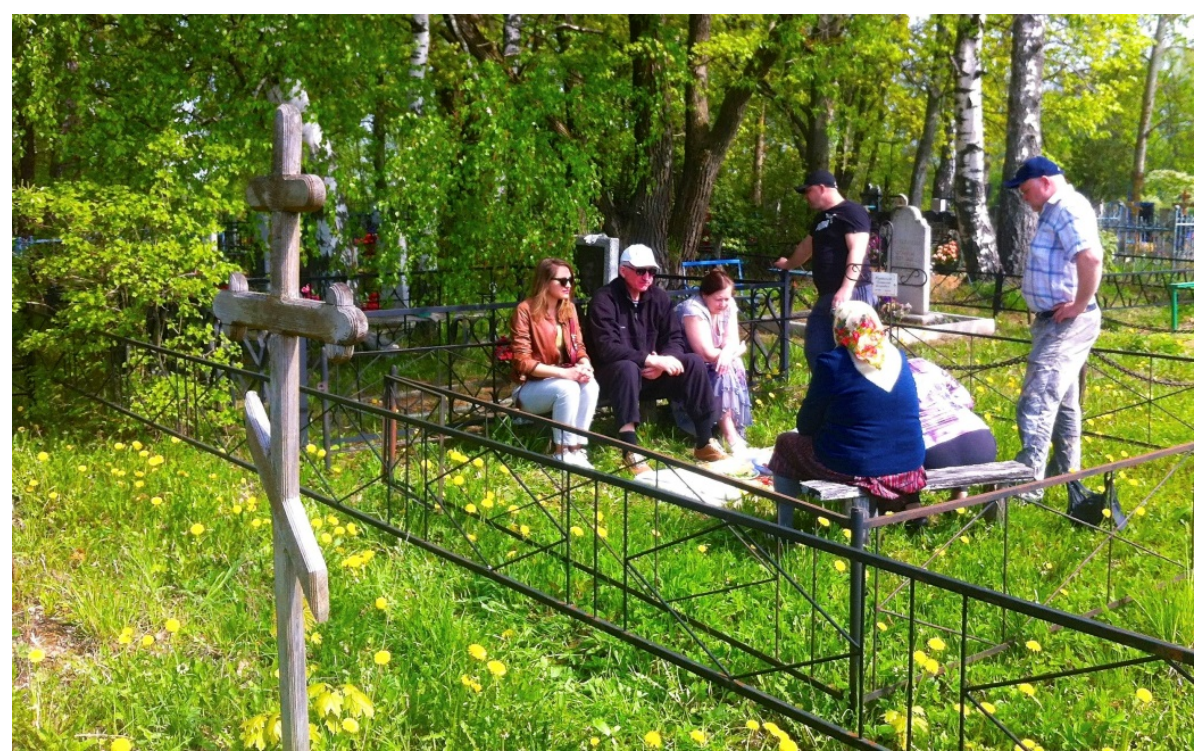

Photo 1. Radonitsa celebration in the village of Vysokoe, Smolensk region, May 2016. Photo taken by the author

In addition to the social integration, radonitsa also presents some religious aspects. As mentioned before, the Soviet period introduced a very strong form of atheism. While people still observed the old rituals conveyed from generation to generation, not all of them followed the official religious observances. Even if the Church recognized and adopted the rite, the people avoided the churches and its priests (Listova 2015: 68). According to my interviewees, very few people ever invited a priest to say a prayer for a departed one. One 51 year old woman said:

I never asked a priest to join our remembrance, and neither did my friends nor my family. Everyone celebrates it in their own way. We bring eggs, pancakes, meat and candles. These are all we bring. And vodka, of course. Some people also bring cognac, whatever they wish to bring. 
This woman emphasizes the individual character of the celebrations. People follow the general scenario of the ritual and bring food and drink. Nonetheless, she disassociates herself from the religious structure and prefers to practice the ritual on her own, as her relatives and acquaintances do. This dichotomy portrays an interesting religiousness. On the one hand, they consider themselves Orthodox and religious, but on the other, they distance themselves from the Church system on this special day. Even if radonitsa is considered as a part of the Easter holidays and contains some of its elements, people follow the old tradition and reject the Church practice. The evidence of longevity of the rite can also be interpreted as a return to the roots of Christianity.

Radonitsa has a different character in villages compared to that in Smolensk. In the provinces, due to work people can start celebrations earlier than it is customary; for example, having to work on farms allows them to begin the celebrations earlier. Sometimes people need to visit more than one cemetery and thus many graves. Furthermore, some of my interviewees believe that it does not really matter when exactly the family visits the graves because it is memory that is the most important thing. In Smolensk the majority of inhabitants visit the graveyards on the first Tuesday after Easter when radonitsa is usually celebrated. Normally people do not have to work on that day or they reduce working hours. On the day of celebration the city administration adds more buses to its public transport system to accommodate the people's needs. This fact shows how powerful and widespread the custom is. The municipal administration recognizes the social needs of its citizens and creates conditions conducive to the celebration of radonitsa.

Some take advantage of the fact that there are many people at cemeteries on this day and do business there. Some sell artificial flowers at the entrance to the cemetery. These flowers are a very popular decorative element. I did not notice anyone bringing fresh flowers or candles as is the case in the Western regions. Artificial flowers are a practical decoration as they never wither; they symbolise a desire to enhance for a long time a place for a soul coming to the world of life. Such a decoration can also be perceived as a form of respect for the departed: to make a nice and pleasant area for them to return to.

\section{Radonitsa and Minorities}

Even though radonitsa refers mostly to the Slavic tradition in Russia, it is worth mentioning that the local minorities adapted themselves to the custom of radonitsa as well. Visiting the cemeteries in Smolensk, we can distinguish two ethnic groups that are different from the others in terms of the design of their graves; the most significant distinguishing elements are those characteristic of the rite of radonitsa. 


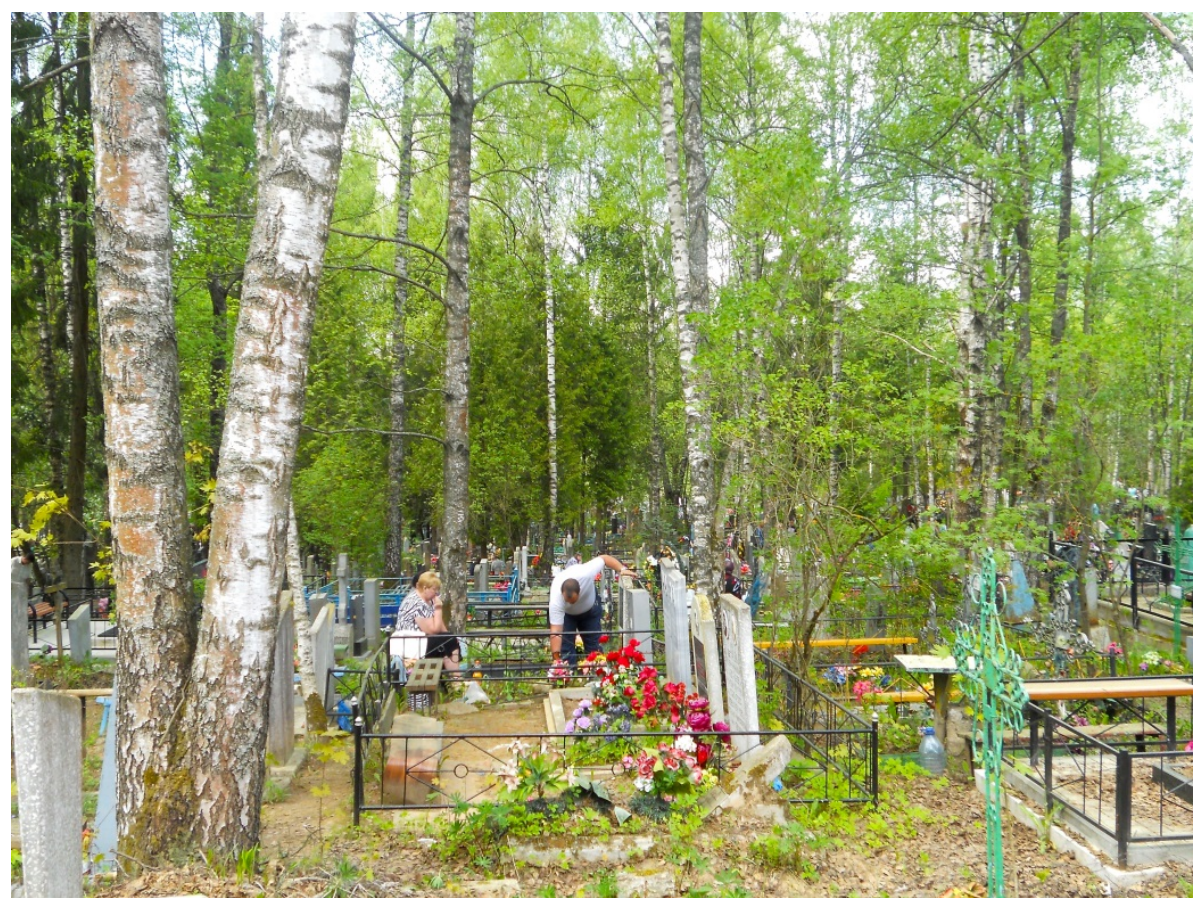

Photo 2. A cemetery in Smolensk during radonitsa, May 2016. Photo taken by the author

The Roma minority in Smolensk have their graves either at the same cemetery or at separate ones but still connected to the municipal cemeteries. They celebrate radonitsa in a more sophisticated manner than the rest of Smolensk inhabitants. Romani people's graves have a special design: a full size marble gravestone with a coloured portrait of the departed covers the grave. The presence of such a gravestone is not typical for the other social groups whose gravestones usually feature only small portraits of the departed. The people I talked to explained that only the Roma minority uses this kind of huge gravestone suggesting a high social status of the departed, with the biggest gravestones and commemoration ceremonies organized for the barons who are the leaders of the Roma community. During radonitsa, Romani graves can be easily noticed: burial places are visited by many people who bring large tables and have a barbecue using professional equipment. The Roma community serves more diverse dishes and alcohol. There is also no social contact between them and the other visitors of the cemetery. The Roma people speak the Roma language which is incomprehensible to the average Russian. Furthermore, the local Roma live a separate life and maximally limit their social contacts with the inhabitants of Smolensk. Nevertheless, they do adopt many local customs. The Roma community accepts 
the faith of the country where they live. The example of radonitsa shows that they can accept the local customs, too.

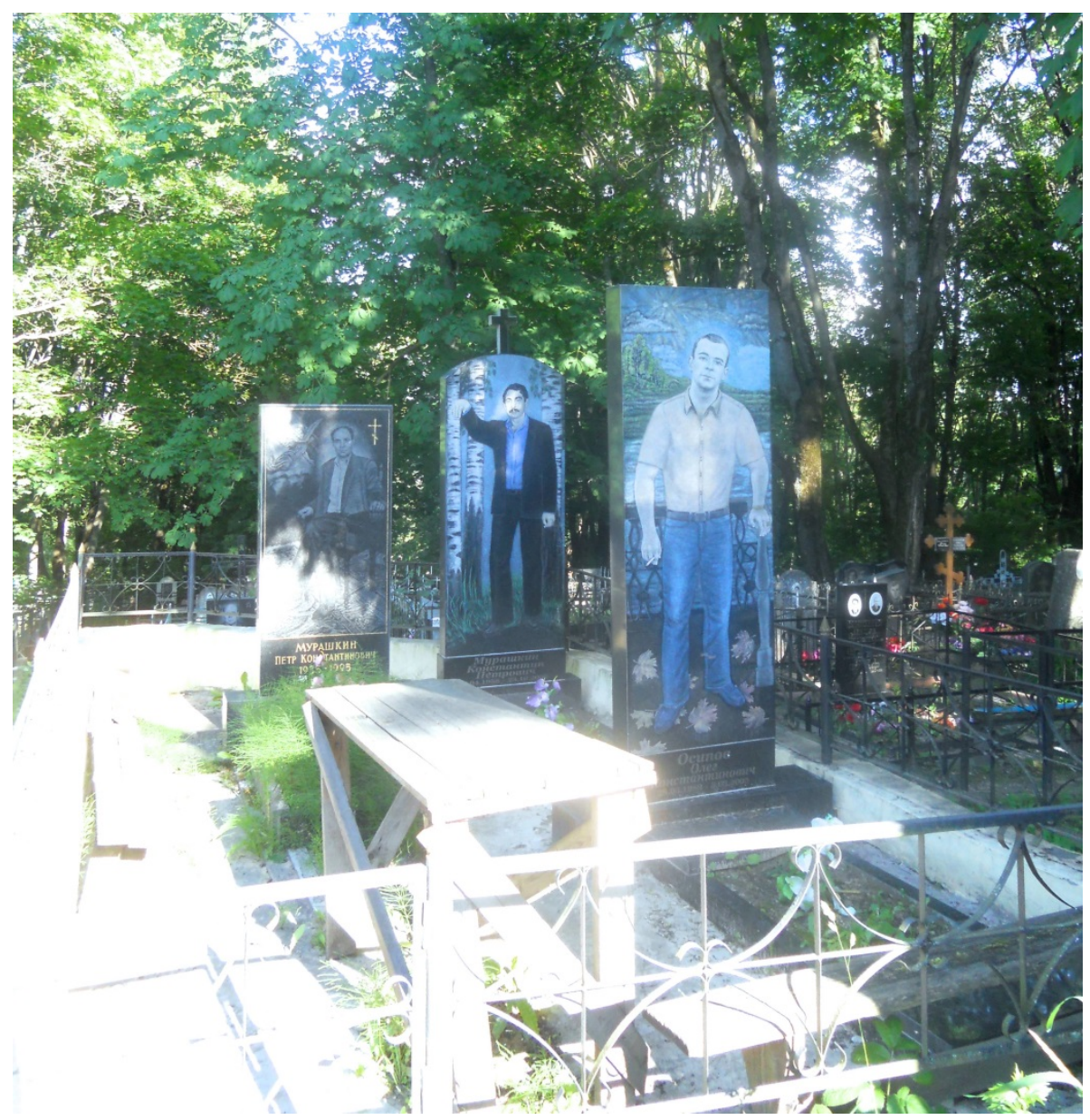

Photo 3. A Roma grave in the Smolensk cemetery. Photo taken by the author

The nature of the Roma community's mobility is responsible for the spread of the radonitsa ritual. For instance, research done among the Roma minority in Poland has shown that the local Roma group has a custom of celebrating their forefathers' remembrance in spring. As the Polish Roma are Catholic, they celebrate the Catholic All Saints Day on the $1^{\text {st }}$ of November. And even then they are accustomed to bring food and alcohol to the cemetery. Some graves have benches and tables (Kowarska 2005: 197). Such a ritual is not typical for other societies in Poland. The most typical way of commemorating there is to put a candle and some fresh flowers on a grave. Placing benches, not tables, is more typical for the Eastern part of Poland 
which is a region adjacent to Belarus where radonitsa-related rituals are very common. The presence of the radonitsa rite among some Roma in Poland can be interpreted as a transfer of the ritual from the East to the West. The local communities in Poland did not adopt the Roma tradition and the Roma did not spread their customs among the others. In this regard it is interesting to note that in the Smolensk region the Roma did in fact adopt this rite.

The Jewish part of the cemetery is located next to the Roma cemetery and according to Jewish laws must be at a certain distance from Christian graves. Jewish gravestones in Smolensk do not represent typical "matzevahs" (a Hebrew name for a gravestone) and display images of the deceased, thus going against the Jewish tradition in this respect. Furthermore, relatives bring flowers to the grave and that is also an act not typical for the Jewish tradition, since according to the custom stones should be placed on gravestones and not flowers. The fact that families install benches can be interpreted as a clear indication of influence of the local ritual of radonitsa. The local Jewish minority has obviously adopted the dominant tradition by following it in their own way.

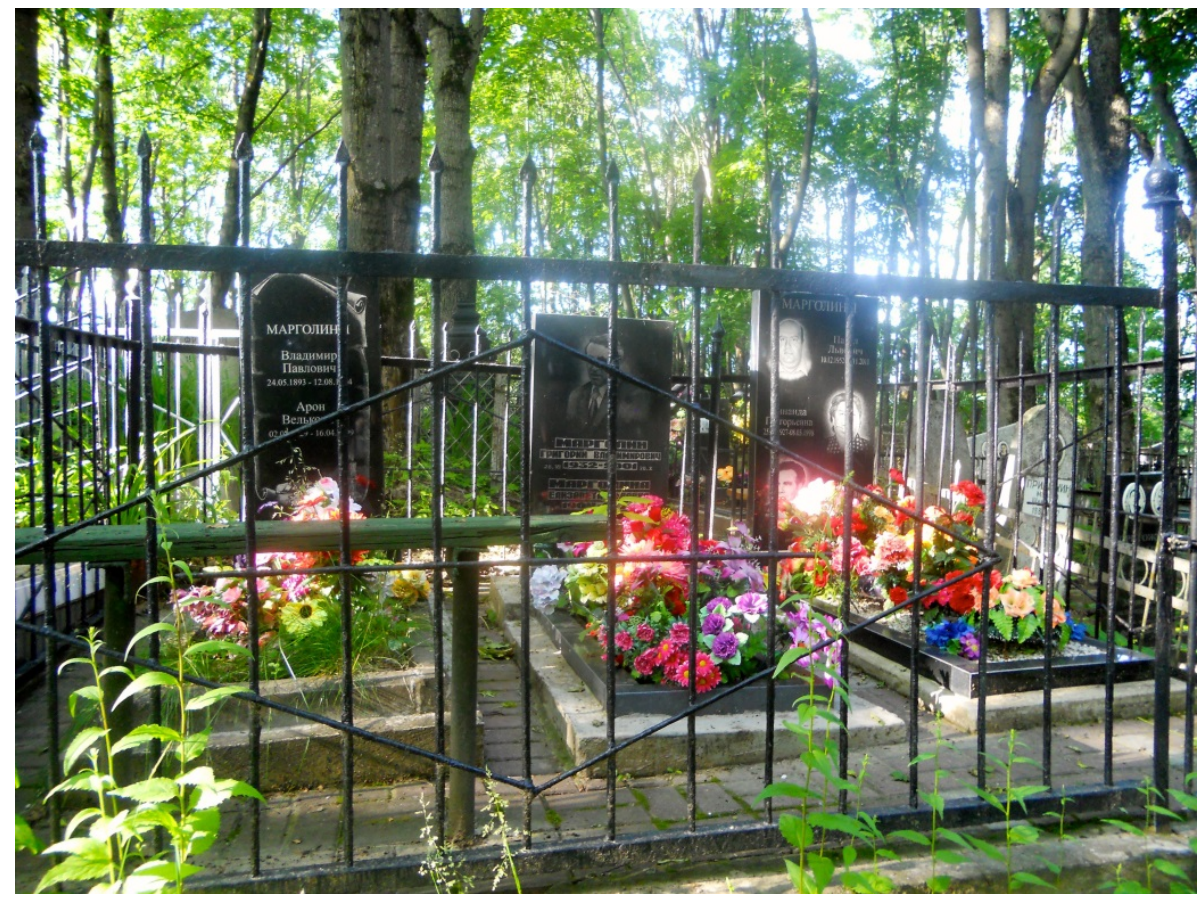

Photo 4. A Jewish cemetery in Smolensk. Photo taken by the author

This fact can also be associated with the Soviet attempts to spread atheism aimed at bringing various ethnicities together. Religion being an important component of identity was considered to be negative as opposed to 
the stated goals of integration and homogenization. Moreover, religion is mainly rooted in conservatism, leaving little room for new tendencies which could over time abolish its dogmas. The Soviet society was mostly atheist and certain religious rituals were discontinued. The way the Jewish cemetery in Smolensk looks right now results from the Soviet policy and not from preferences of the Jewish people who did not receive enough knowledge that would enable them to follow the rules of their religion. For them the process of memory transmission was dismantled whereas Orthodox families could still continue celebrating their religious holidays in public. The Jewish minority in Smolensk adopted the custom of radonitsa which is a typical ritual well-known among and practiced by the overwhelming majority of the population. It is only nowadays when it is possible to return to one's roots and regain a Jewish identity that the people start joining the Jewish community and perform Jewish rituals again in accordance with the Jewish tradition. This tendency can also be observed at the Jewish cemetery. When new graves are laid out according to the Jewish law, many people still continue to perform the ritual of radonitsa: benches, portraits, artificial flowers and empty glasses are all a sign of this.

Thus, the examples of both minorities, the Roma and the Jewish, are a very interesting result of assimilation and continuity in the radonitsa tradition. This proves that the local ritual is very powerful and attractive for different groups. The ritual is meaningful as it enhances and preserves family bonds as well as keeps the memory of the departed ones alive. Such an idea does not ideologically contradict any religious beliefs, and this has resulted in a cross-cultural process currently taking place. This is also noticeable in the propagation and adaption of radonitsa in other Russian regions. Even though the ritual was not previously known, people still observe it as the idea of connecting with their ancestors is both attractive and positive.

\section{Summary}

The aim of this article was to present the historical origins of radonitsa, as well as its continuity, meaning and current framing. It gives a broad picture of three religious groups living in the Smolensk region: the Orthodox majority and the Jewish and Roma minorities. Radonitsa is a binding element for all of them: it is performed in one place and at one time but in a bit different ways.

This article presents the results of the research conducted in 2016 in the Smolensk region. It is based on participant observation and interviews with people who agreed to introduce me to their private circle. They allowed me to observe and perform the commemoration ritual of radonitsa.

In comparison to other available scientific material on this topic, this article focuses on the description of the rite in a particular place, shows a historical perspective and adopts a cross-cultural approach. 
Radonitsa is a unique example of a ritual with ancient origins which has survived through centuries. The continuity of practicing the ancient tradition is an extraordinary case to be found in modern society. Death as a ritual of passage (van Gennep 1960) has been cultivated by societies for ages and has played an important role in understanding the meaning of human life in the world as well as helped to anchor people in moral frameworks. Rituals connected with death raise existential questions and manifest the human role in the general cosmogenic world. Modern society by stopping the practice of such rituals deprives itself of the possibility of this understanding (Giddens 1991: 272). The inhabitants of the Smolensk region do not have such a problem since the tradition has been transmitted from generation to generation. Although many of my interlocutors had no knowledge about the origins of this ritual, they considered it to be a typical element of their daily life. Radonitsa has been present in the life of their family and ancestors for ages. The young generation maintains the ritual by participating in it with their families, thus safeguarding the stability and continuity of the rite for the future.

As the research results show, the people from the Smolensk region who took part in this project cope with the mystery of death with joy. The positive element is included in the name of the ritual itself: the core word "rad" means "joy". By means of symbolic invitation of the ancestors from the world of death to the world of life, the people connect with them and create an atmosphere of self-reflection. A grave with a tablecloth becomes a festive table for the whole family. The dead souls receive symbolic food in the form of poured alcohol and food leftovers.

Radonitsa is a festival of spring when nature returns after a cold winter. The ritual is connected with Easter and occurs on the first Tuesday after Easter; however, some families observe it on different days which all fall around Easter. The resurrection of Jesus Christ is connected with symbolic resurrection of the memory of the departed. Visiting the gravestones of ancestors is a symbolic connection of life and death. Relatives and friends treat the departed as someone who are still present among them and so they organize a feast for them. This ritual does not limit itself to the closest family circle. The rite is characterized by great hospitality. Families invite relatives, acquaintances and even strangers to join the celebrations. In this way the rite of incorporation also takes place (van Gennep 1960). People reunite the living family members with the deceased ones, restore social change and incorporate everyone into the private community. Thus, radonitsa is a social commemoration ritual performed in public.

The other ethnic groups and regions in the Russian Federation have adopted this rite because of its appeal. In the case of the Smolensk region this was observed among the Roma and Jewish communities. The ritual makes such a powerful impression that it is treated as a Russian national commemoration tradition. The Orthodox Church accepted it and presents it 
as an element of folk culture since the ritual is performed in accordance with the Christian belief of life existing after death.

The origins of radonitsa can be found in ancient times. The belief that a soul after death has the same needs as a living person comes from ancient Egypt, Greece and Rome. This belief became prevalent in the populations of the Mediterranean. It can be seen that the ritual of radonitsa came to the Smolensk region through Byzantium and has persisted here to this day.

People come to cemeteries to celebrate radonitsa with their families. The young people I talked with treat radonitsa as a custom and respect its meaning. They participate in the ritual together with their parents and find it an important way to commemorate their forefathers. Since knowledge about the tradition is transmitted within a family through memory, the ritual will most certainly continue into the future.

\section{Notes}

${ }^{1}$ Later, my own research led me to the distant past and to the regions further away from Smolensk where rites similar to radonista were performed.

${ }^{2}$ This popular custom still exists in the Smolensk region today.

${ }^{3}$ Data available on https://wciom.ru/index.php?id=236\&uid=13365

\section{References}

Agapkina T.A. Mifologicheskie osnovy slavyanskogo narodnogo kalendar'a. Vesenne-letniy cikl [The mythological foundations of the Slavic people's calendar. The spring to summer cycle]. Moscow: INDRIK, 2002.

Ambos, C., Weingold, J., Rahmen und Rahmungsprozesse. In: Brosius, Ch., Michaels, A.; Schrode, P. (Hg.). Ritual und Ritualdynamik. Schlüsselbegriffe, Theorien, Diskussionen. Göttingen: Vandenhoeck \& Ruprecht, 2013, pp. 92-99.

Chugaeva S.V., Semik - den' pominoveniya umershih u komi-prermyakov [Semik, a remembrance day as celebrated by the Komi-Permyaki], Vestnik VGU, 2010, no. 1, pp. 200208.

Dayneko, T. Fol'klornye tradicii sela Kolbasa: osnovnye vehi narodnogo kalendarya [Folk traditions of the village of Kolbasa: folk calendar major stages (according to Eva Ivanovna Pavlyukova's memories)], Yazyki i folklor korenyh narodov Sibiri, 2016, no. 2 (31), pp. 63-70.

Fischer, A. Zwyczaje pogrzebowe ludu polskiego. Lviv: Wydawnictwo im. Ossolińskich, 1921.

Fischer, A. Święto umarlych (Fête des morts). Lviv: Nakład Muzeum im. Dzieduszyckich, 1923.

van Gennep, A. The Rites of Passage. Chicago: The University of Chicago Press, 1960.

Gluckman, M. Rituals of Rebellion in South-East Africa. Manchester: Manchester University Press, 1954.

Giddens, A. Modernity and Self-Identity. Self and Society in the Late Modern Age. Cambridge: Polity Press, 1991.

Gołąbek, J. Dziady biatoruskie. Lviv: Towarzystwo Ludoznawcze, 1926.

Huntingdon, R., Metcalf, P. Celebrations of Death: The Anthropology of Mortuary Ritual. (2nd ed.), Cambridge, UK: Cambridge University Press, 1991.

Janion, M. Niesamowita stowiańsczyzna. Kraków: Wydawnictwo Literackie, 2006. 
Kapferer, B. Dynamics. In: Kreinath, J., Snoek, J. and Stausberg, M. (eds.) Theorizing Rituals. Classical Topics, Theoretical Approaches, Analytical Concepts. Boston, Leiden: Martinus Nijhoff Publishers and VSP, 2008, pp. 511-513.

Kazakova, I., Ėtničnyâ tradycyì ǔ duhoǔnaj kul'tury Belarusaǔ. Minsk: Unìversìtèckae, 1995.

Kopaliński, W. Stownik symboli. Warsaw: PWN, 1997.

Kowarska, A. Polska Roma. Tradycja i nowoczesność. Warsaw: Wyd. DiG, 2005.

Kupisiński, Z. Dzień zaduszny w liturgii i tradycji ludowej, Roczniki Teologiczne, 2006, Vol. 2, no. 9, pp. 12-34.

Lewicki, T. Obrzędy pogrzebowe pogańskich słowian. In: Archeologia v 1952-1953, 1955, pp. 3-18.

Listova, T. Regional'nye transformacii pohoronno-pominoval'nogo obryada [Regional transformations of the burial-and-waking rite]. In: Sokolova D.A., Yudkina A.B. (eds.), Momento Mori: Pohoronnye tradicii v sovremennoy kul'ture [Momento Mori: burial traditions in contemporary culture]. Moscow: IEA RAN, 2015, pp. 54-77.

Michaels, A. Zur Dynamik von Ritualkomplexen, Forum Ritualdynamik, 2003, Vol. 3.

Pankeev I.A. Obychai i obriady russkogo naroda. Ot krestin do pominok [Customs and rites of the Russians. From christening to waking]. Moscow: Astrel, 2008.

Rachinskiy A.V., Fyodorov A.E. Russkaya cerkov' - hranitel'nitsa narodnoy dohristyanskoy kul'tury [The Russian Church as a keeper of pre-Christian folk culture]. Moscow: Masterskaya malotirazhnoy poligrafii, 2016.

Sokolova, V. Vesenne-letnie kalendarnye obrâdy russkih, ukraincev i belorusov XIX-načalo $X X v$. [The spring to summer calendar rites of the Russians, Ukrainians, and Belarussians in the $19^{\text {th }}$ to the early $20^{\text {th }}$ centuries]. Moscow: Nauka, 1979.

Sokolova D.A., Yudkina A.B. (Eds.) Momento Mori: Pohoronnye tradicii v sovremennoy kul'ture [Momento Mori: burial traditions in contemporary culture]. Moscow: IEA RAN, 2015. 